\title{
Klasyfikacje projektów informatycznych w kontekście ich efektywności
}

https://doi.org/10.33141/po.2005.01.09

Przegląd Organizacji, Nr 1 (780), 2005, ss. 38-40 www.przegladorganizacji.pl

Aleksander Lotko Towarzystwo Naukowe Organizacji i Kierownictwa (TNOiK)

\section{Wprowadzenie}

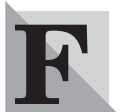

aktem jest, że inwestycje w rozwiązania informatyczne wspomagające biznes, zwłaszcza na poziomie strategicznym, charakteryzuja się dużymi trudnościami w wymiernym określaniu tak kosztów, jak i korzyści. Wynika to z ogromnego znaczenia zasobów niematerialnych i nieuchwytnych efektów. Zdaniem autora problematyka wiarygodnej i kompleksowej oceny rzeczywistych efektów informatyzacji należy obecnie do najtrudniejszych i najpilniejszych zadań na polu matematyki finansowej. Szacuje się, że jedynie około $18 \%$ organizacji bada efektywność rozwiązań informatycznych (w Stanach Zjednoczonych i Europie Zachodniej) przy użyciu miar finansowych, przy czym prawdopodobieństwo użycia narzędzi formalnych rośnie wraz ze wzrostem wielkości organizacji i/lub budżetu przeznaczonego na projekt informatyczny [Edwards 2003]. W obszarze tym zalecane są następujące poczynania [Edwards 2003, Lotko 2003]:

- rozwiązania informatyczne muszą być zdeterminowane strategią biznesową i pełnić wobec nich jedynie służebną rolę (chociaż nieraz otwierają nowe możliwości), a nie odwrotnie - wydatki na technologie informatyczne muszą być uzasadnione zgodnością z wymogami biznesu,

- należy szacować zwrot z inwestycji informatycznych; wskaźniki te są często niedoceniane.

\section{Efektywność a wydajność w projektach informatycznych}

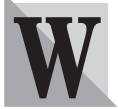

informatyce efektywnością nazywa się relacje pomiędzy całkowitym nakładami a efektami, a ocena efektów ujęta jest w użyteczności, czyli próbie odpowiedzi na pytanie, czy potrzeby informacyjne użytkowników systemu informatycznego zostały zaspokojone [Kisielnicki 1993].

Należy dokonać wyraźnego rozróżnienia efektywności od wydajności [Pańkowska 2001]. O ile wydajność jest pożądanym celem organizacji, bycie wydajnym nie zawsze oznacza, że jest się efektywnym. Wydajność przedsięwzięć informatycznych jest definiowana jako poszukiwanie sposobności redukcji kosztów wykonania poszczególnych procesów lub zadań na poziomie operacyjnym. Nie oznacza radykalnej zmiany celów zadań i procesów, które są realizowane, ale zmierza do ich realizacji po niższych kosztach. Korzyści można więc obserwować przede wszystkim w zakresie redukcji lub przemieszczenia kosztów [Fitzgerald 1998]. Wydajność jest tu więc tożsama z efektywnością operacyjną, a także, w pewnym zakresie, finansową. Natomiast podstawowym celem określania efektywności przedsięwzięć informatycznych nie jest prosta redukcja kosztów wykonania obecnych zadań, ale identyfikowanie sposobów wykonania zadań, które w lepszy sposób pozwolą osiągnąć pożądane rezultaty ekonomiczne, doprowadzą do wzrostu dochodów czy lepszej obsługi klientów. W takim znaczeniu efektywność nie ogranicza się do kryteriów wydajnościowych, ale jest poszukiwaniem sposobów poprawy funkcjonowania całej organizacji [Pańkowska 2001]. To podejście dotyczy więc wydajności rynkowej i rozwojowej, a także finansowej.

Zatem wydajność związana jest ze sposobem wykonywania zadań, efektywność zaś dotyczy samego zadania w kontekście całej organizacji. Ocena efektywności przedsięwzięć powinna być oparta na kryteriach takich, jak wzrost funkcjonalności, wyższa jakość, poprawa pozycji konkurencyjnej. Ocena efektywności to ocena uzyskania pożądanego efektu czy osiąnięcia zamierzonego celu, uwzględniająca związane z tym nakłady [Pańkowska 2001]. Efektywność jest oceniana tym wyżej, w im większym stopniu zrealizowano zamierzenia czy osiągnięto cel. Jeśli efekty i nakłady dają się wyrazić w tych samych jednostkach, to można je porównać i stwierdzić, czy osiagnięte efekty przewyższają nakłady, a więc czy przedsięwzięcie jest opłacalne. Jest to tzw. efektywność bezwzględna, w przeciwieństwie do efektywność względnej, polegającej na porównaniu $\mathrm{z}$ inną organizacją lub z normą (benchmarking).

Efektywność informatyzacji jest definiowana w kategoriach nakładów i wynikających z wdrożenia strategii organizacji oraz jej strategii informatyzacji. Przyjmuje się, że dana funkcja systemu informatycznego jest użyteczna i wykonywana poprawnie, jeżeli jej efekt przyczynia się do osiągnięcia celu organizacji jako całości, czyli lepszego zarządzania, przy założeniu wewnątrzorganizacyjnej zgodności celów gospodarczych. Ocena inwestycji w technologie informatyczne nie jest zadaniem nowym. Próby szacowania kosztów i efektów informatyzacji podejmowane były od początków automatyzacji przetwarzania informacji gospodarczych. Inwestycje w systemy informatyczne powinny być przedmiotem badań $\mathrm{z}$ następujących powodów [Pańkowska 2001]:

- zwiększa się część budżetu organizacji przeznaczana na rozwiązania informatyczne; 
- inwestycje w informatykę często nie są postrzegane jako istotnie powiązane z dochodami i zyskiem, stąd związek ten należy silniej wyeksponować;

- istotna część wydatków na technologieinformatyczne podlega kapitalizacji;

- użytkownicy żądają ciągłej gotowości systemów informatycznych, co wymaga specyfikacji miar oceny poziomu usług informatycznych.

Można sklasyfikować trzy główne nurty oceny przedsięwzięć informatycznych [Kasprzak 2003]:

- nurt techniczno-funkcjonalny, który zakłada, że skutki inwestycji w systemy informacyjne sa krótkookresowe i nie mają związku ze strategią biznesu; założenia tego nurtu sa poprawne w stosunku do prostych systemów automatyzacji;

- nurt ekonomiczno-finansowy, który traktuje inwestycje w informatykę jako inwestycje skierowane na wzrost efektywności biznesu lub rozszerzenie jego pola; ocena przesuwa się tu od projektu traktowanego w izolacji do jakości jego produktów lub świadczonych usług na rzecz klientów wewnętrznych i zewnętrznych; można tu stosować m.in. techniki ocen projektów wywodzące się z zarządzania wartością;

- nurt możliwych interpretacji, wynikający ze specyfiki inwestycji informatycznych; uwzględnia on cały cykl życia projektu, łacznie z nakładami i korzyściami w jego trakcie, a nacisk kładziony jest na kontekst decyzyjny, w jakim projekt występuje.

W tabeli podano zestawienie trzech nurtów oceny projektów informatycznych.

\section{Klasyfikacje projektów informatycznych ze względu na efektywność}

W

ewolucji technologii informacyjnych oraz ich wpływie na organizacje gospodarcze wyróżnia się pięć fal innowacyjnych [Kasprzak 2003]:

- fala redukcji kosztów; początkowe zastosowania informatyki w biznesie ukierunkowane były na wzrost produktywności i redukcję kosztów poprzez automatyzację procesów,
- fala wywołująca wzrost efektywności inwestycji dzięki lepszemu wykorzystaniu zasobów,

- fala ulepszeń (rozwoju nowych produktów i usług); technologie informacyjne służyły do generowania nowych produktów i linii biznesowych, informatykę ukierunkowano na funkcje zewnętrzne organizacji: marketing, dystrybucję i obsługę klientów,

- fala wspierająca procesy decyzyjne; związana jest z wdrażaniem systemów wspomagających zarządzanie, - fala wspierajacca relacje z klientami; informatyka wkracza tu na teren bezpośredniej komunikacji z klientami i powoduje restrukturyzacje całych sektorów, notuje się nowy typ strategii skierowanych na klienta: marketing partnerski i zarządzanie relacjami z klientem; dominujące znaczenie mają techniki komunikacji sieciowej.

Dwie pierwsze fazy nastawione były na oszczędności i wynikały ze strategii redukcji kosztów, lecz nie podejmowano wówczas tematu wzrostu organizacji i korzyści strategicznych wynikających z zastosowania informatyki. Od fazy trzeciej zaczęto się kierować względami korzyści strategicznych organizacji.

Ostatnia dekada XX wieku przyniosła ogromny wzrost nakładów na biznesowe zastosowania informatyki. Fascynacja możliwościami oferowanymi przez nowe technologie prowadziła często do podejmowania decyzji o ograniczonej racjonalności. Często argumentem przemawiającym za kupnem danego rozwiązania było jego nabycie przez konkurencję. Podejście to prowadziło do zakupów rozwiązań modnych, często nie sprawdzonych, nieraz do wdrożeń oderwanych od rzeczywistości biznesowej i nieuzasadnionych ekonomicznie. Koniecboomu internetowego pociagnął za soba znacznie większa ostrożność inwestorów [Janowski 2003]. Obecnie wiele organizacji traktuje informatykę tak samo, jak inne inwestycje. Informatyka jest zmuszona rywalizować o środki finansowe z produkcja, sprzedażą, czy marketingiem. Takie podejście weryfikuje znaczenie rozwiązań informatycznych w organizacji [Janowski 2003]. Jednocześnie inwestycje w rozwiązania informatyczne stanowią dziś w znacznym stopniu o konkurencyjności biznesu. Zajęcie dobrej

Tab. Porównanie trzech nurtów oceny projektów informatycznych [Serefeimidis 2001]

\begin{tabular}{|c|c|c|c|}
\hline \multirow{2}{*}{ Wymiar } & \multicolumn{3}{|c|}{ Nurt } \\
\hline & techniczno-funkcjonalny & ekonomiczno-finansowy & możliwych interpretacji \\
\hline Cel & $\begin{array}{c}\text { Sprawność techniczna, kontrola } \\
\text { zasobu informatycznego, } \\
\text { koszty utrzymania systemu }\end{array}$ & $\begin{array}{l}\text { Jakość i stopień wykorzystania } \\
\text { systemu i skutków jego } \\
\text { wprowadzenia }\end{array}$ & $\begin{array}{c}\text { Rozwiązania wrażliwe } \\
\text { na kontekst, } \\
\text { uczenie się organizacji }\end{array}$ \\
\hline $\begin{array}{l}\text { Przedmiot oceny, } \\
\text { stosowane } \\
\text { kryteria }\end{array}$ & $\begin{array}{l}\text { System informatyczny, } \\
\text { automatyzacja, } \\
\text { redukcja kosztów }\end{array}$ & $\begin{array}{l}\text { Produkt systemu } \\
\text { informatycznego: } \\
\text { produkcyjność, } \\
\text { wartość firmy, } \\
\text { satysfakcja użytkowników }\end{array}$ & $\begin{array}{c}\text { Portfele systemów } \\
\text { informatycznych, } \\
\text { pomiary efektów pośrednich }\end{array}$ \\
\hline $\begin{array}{l}\text { Horyzont } \\
\text { czasowy }\end{array}$ & $\begin{array}{c}\text { Ex ante i ex-post inwestycji, } \\
\text { cykl życia systemu }\end{array}$ & $\begin{array}{l}\text { Ex ante i ex-post } \mathrm{w} \text { relacji } \\
\text { do cyklu życia systemu }\end{array}$ & Ciagłe zarządzanie efektami \\
\hline $\begin{array}{l}\text { Rola ludzi } \\
\text { w procesie oceny }\end{array}$ & Eksperci informatyki & $\begin{array}{l}\text { Eksperci informatyki, } \\
\text { menedżerowie finansowi }\end{array}$ & $\begin{array}{c}\text { Uczestnicy procesu oceny, } \\
\text { wewnętrzni i zewnętrzni } \\
\text { odbiorcy usług informatycznych }\end{array}$ \\
\hline $\begin{array}{l}\text { Stosowana } \\
\text { metodologia }\end{array}$ & Związana z jakością i kosztami & $\begin{array}{l}\text { Orientacja ekonomiczna, } \\
\text { finansowa i behawioralna }\end{array}$ & Rozwój metametodologii \\
\hline Założenia & Efektywność kosztowa & Efektywność systemowa & Rozumienie problemu \\
\hline
\end{tabular}


pozycji rynkowej i konkurowanie na nowych rynkach jest właściwie niemożliwe bez posiadania stosownych systemów informatycznych. Inwestycje w technologie informatyczne można pogrupować następująco [Pańkowska 2001]:

- inwestycje bezwzględnie konieczne, np. wymagane normami prawnymi, jak systemy finansowo-księgowe, rozliczeń ZUS itp.;

- inwestycje dla poprawy wykonania, np. wyposażenie agentów ubezpieczeniowych w przenośne komputery w celu umożliwienia pracy poza biurem;

- inwestycje przewagi konkurencyjnej, polegające na implementacji innowacyjnych, unikalnych rozwiązań; - inwestycje infrastruktury, np. w urządzenia telekomunikacyjne, sieci komputerowe;

- inwestycje badawcze, np. w narzędzia wspomagania budowy oprogramowania użytkowego.

Z kolei z punktu widzenia konkurencyjności rozwiązań można mówić o trzech grupach systemów informatycznych dla biznesu. Różnią się one ryzykiem wdrożenia i zakresem oferowanych korzyści. Podział ten obejmuje [Gruchman 2003]:

- systemy awangardowe, które służą pionierskim organizacjom do zdobywania zdecydowanej przewagi konkurencyjnej (dziś zaliczyć tu można sklepy internetowe czy publiczne rynki elektroniczne);

- systemy konkurencyjne, które mogą znacząco polepszyć wyniki organizacji i wzmocnić jej pozycję w macierzystym sektorze (należą tu $\mathrm{np}$. systemy zarządzania łańcuchem dostaw, hurtownie danych, systemy zarządzania relacjami z klientem);

- systemykonwencjonalne,których zastosowaniejest koniecznością i które funkcjonują w większości organizacji, przede wszystkim przyczyniając się do redukcji kosztów procesów informacyjnych (są to najczęściej systemy transakcyjne).

Wdrożenia systemów awangardowych niosą ze sobą duże ryzyko, a korzyści sa niepewne (systemy te nie zawsze się sprawdzaja). Z kolei systemy konwencjonalne sa immanentnym elementem struktury informacyjnej organizacji. W związku z tym sugeruje się [Gruchman 2003], aby uwaga organizacji koncentrowała się na wdrażaniu systemów konkurencyjnych, ze względu na korzystna relację pomiędzy ryzykiem a korzyściami. Spostrzeżenie to dotyczy więc także informatycznego wspomagania centrum kontaktu $\mathrm{z}$ klientem.

Wprowadza się też alternatywne podziały. Przykładowo można zdefiniować [Lin, Pervan 2001]:

- systemy strategiczne - płynące z nich korzyści sa rezultatem innowacji i zmian w prowadzeniu biznesu, pozwalają na uzyskanie przewagi konkurencyjnej; - podstawowe systemy operacyjne - korzyści z ich stosowania sprowadzają się do bardziej efektywnego przebiegu procesów w organizacji;

- systemy wspomagające - ich celem jest redukcja kosztów poprzez intensyfikację działań (większą sprawność);

- systemy wysokiego potencjału - ich implementacja wiąże się ze znacznym ryzykiem, aktualnie nie są stosowane i mogą być rozważane jak fragment obszaru badawczego organizacji.

Proponuje się także podział systemów informatycznych na [Lin, Pervan 2001]:

- projekty obowiązkowe, wynikające ze stanu zaawansowania informatyzacji w sektorze, projekty podwyższające sprawność (skuteczność) działania,

- inwestycje bezpośredniego znaczenie konkurencyjnego,

- inwestycje w infrastrukturę informatyczną,

- inwestycje w badania dotyczące informatyki (narzędzia wspomagające modelowanie itp.).

\section{Efektywność systemów informatycznych a konkurencyjność organizacji}

W kontekście rozważań nad konkurencyjnościa systemów informatycznych i traktowania informatyki jako inwestycji ważny jest fakt, że istnieją dziś trzy główne obszary, w których obserwuje się dyskusje nad rolą informatyki w biznesie. Sa to [Kubat 2003]:

- Traktowanie informatyki jako inwestycji; sprawdzanie, czy wdrażane rozwiązania rzeczywiście wspomagają w sposób efektywny procesy organizacji, czy przynoszą pożądane efekty ekonomiczne w postaci wzrostu zysków lub ograniczania kosztów. Jest to bardzo ważny kierunek badań nad rolą informatyki w biznesie. Chodzi tutaj o zharmonizowanie technologii informatycznych ze strategią organizacji oraz wybór właściwych rozwiązań.

- Współpraca z dostawcami technologii i usług, obejmująca outsourcing, profesjonalizację organizacji projektów, organizację wsparcia technicznego itp.

- Zarządzanie infrastrukturą i technologia informatyczną, a więc kwestie związane $\mathrm{z}$ racjonalizacja kosztów technologii informatycznej, integracją systemów, zapewnieniem bezpieczeństwa, zarządzaniem danymi, zarządzaniem wydajnościa itp.

Szczególne znaczenie ma wybór rozwiązania informatycznego. Waga tej decyzji wynika $\mathrm{z}$ faktu, że wdrażane rozwiązania wpływają również na strategiczne podejście organizacji do zarządzania kontaktami z klientami w dłuższej perspektywie czasowej. Istotność tej decyzji pociąga za sobą wymagania wobec jej właściwego uzasadnienia i oszacowania skutków na wszystkich szczeblach zarządzania. Kluczową kwestią pozostaje dostosowanie zasobów technologicznych i innych do rzeczywistych potrzeb biznesowych oraz efektywne nimi zarządzanie w celu zapewnienia maksymalnego zwrotu z inwestycji [Lotko 2003]. Wybór najlepszego sposobu realizacji przedsięwzięcia informatycznego jest podstawowym warunkiem końcowego sukcesu. W fazie strategicznej rozważanych jest często kilka rozwiązań, z których następnie wybiera się jedno. Należy ponadto pamiętać, że istnieją dwa podstawowe źródła trudności w porównywaniu tych rozwiązań [Jaszkiewicz 1997]:

- wielość celów przedsięwzięcia, czyli wielość kryteriów oceny porównywanych rozwiązań,

- niepewność, czyli fakt niemożliwości precyzyjnej oceny spodziewanych rezultatów wyboru danego rozwiązania.

\section{Podsumowanie}

1 ałość czynników związanych z wyznaczeniem ekonomicznych efektów zastosowań informatyki można podzielić na dwie grupy [Pańkowska 2001]:

- czynniki koncepcyjne, modelowe, których celemjest określenie rodzajów skutków ekonomicznych, 
- czynniki rachunkowe, zmierzające do oceny wyróżnionych uprzednio skutków, czyli wyrażenia ich w wielkościach liczbowych.

Powyższy umowny podział podkreśla znaczenie dwóch grup czynników, nie oznaczając faktycznej możliwości ich rozgraniczenia (w praktyce druga grupa stanowi instancje - konkretne wystąpienia - czynników z grupy pierwszej).

Ocena efektywności informatyzacji wymaga rozwoju metod oceny i ustalenia przesłanek oceny oraz celu badania. Ogólnie, organizacje zmierzają ku temu, aby posługiwać się jak najbardziej obiektywnymi ocenami. Można przyjąć, że do wygenerowania oceny obiektywnej przyczynia się zastosowanie metod proceduralnych, czyli takich sposobów wnioskowania, w których decydent pozwala metodzie (lub narzędziu) na wskazanie decyzji. W rezultacie za najbardziej efektywne zostaje uznane przedsięwzięcie o najwyższej randze pewnego parametru ilościowego. Decydent ustala tu procedurę jako serię operacji na danych (modelu). Procedura redukuje złożoność charakterystyk przedsięwzięcia i sprowadza wnioskowanie o efektywności do jednej miary [Pańkowska 2001]. Proponowane klasyfikacje systemów informatycznych ze względu na ich efektywność powinny umożliwić lepsze koncepcyjne, holistyczne rozumienie efektów, jakie niosa wdrożenia informatyki w organizacji i tym samym umożliwić następnie racjonalne przeprowadzenie takiej procedury.

dr Aleksander Lotko

Politechnika Radomska, Wydział Ekonomiczny

\section{BIBLIOGRAFIA}

[1] EDWARDS J., Jak tam, panie dyrektorze, $z$ ROI informatyki (wyciagg z raportu Getronics, IDG Research i CXO), CXO" 3/2003.

[2] FITZGERALD G., Evaluating Information Systems Projects: A Multidimensional Approach, „Journal of Information Technology" 11/1998.

[3] GRUCHMAN G., Między awangarda a standardem, CXO" 3/2003.

[4] JANOWSKI A., Księgowość, kadry, informatyka, „CXO” 7/2003.

[5] JASZKIEWICZ A., Inżynieria oprogramowania, Helion, Gliwice 1997.

[6] KASPRZAK T., Biznes i technologie informacyjne. Perspektywa integracji strategicznej, Katedra Informatyki Gospodarczej i Analiz Ekonomicznych, Uniwersytet Warszawski, Warszawa 2003.

[7] KISIELNICKI J., Informatyczna infrastruktura zarzadzania, PWN, Warszawa 1993.

[8] KUBAT M., Spodziewana zmiana akcentów, „CXO” $3 / 2003$.

[9] LIN Ch., PERVAN G.,A Review of IS-IT Investment Evaluation and Benefits Management Issues, Problems and Processes, [w:] W.V. GREMBERGEN (red.), Information Technology Evaluation Methods and Management, Idea Group Publishing, London 2001.

[10] LOTKO A., Ocena ekonomicznej efektywności inwestycji $w$ systemy informatyczne typu help desk, Wydawnictwo Politechniki Radomskiej, Radom 2002.

[11] LOTKO A., Zarzadzanie relacjami $z$ klientem. Strategie i systemy, Wydawnictwo Politechniki Radomskiej, Radom 2003.

[12] McNURLIN B., SPRAGUE R. H., Information Systems Management in Practice, Prentice Hall, New Jersey 2000

[13] PAŃKOWSKA M., Zarzadzanie zasobami informatycznymi, Difin, Warszawa 2001.

[14] SEREFEIMIDIS G., A Review of Research Issues in Evaluation of Information Systems, [w:] W.V. GREMBERGEN (red.), Information Technology Evaluation Methods and Management, Idea Group Publishing, London 2001. 